\title{
Chapter 4 Alternative Facts, Misinformation, and Fake News
}

\subsection{Alternative Facts}

Some very specific topics stole the show the day Trump was inaugurated as president on January 20, 2017. The limelight topics are related to simple questions about the facts of the day: Did the sun shine or not during the inauguration speech? How large was the crowd? Was this crowd larger or smaller than the one present at President Obama's first inauguration? It seemed clear from available photos and video footage that the sun did not shine at any point during Trump's speech. Nonetheless, Trump claimed otherwise later that same day during his speech at Langley Air Force Base:

The rain should have scared them away. But God looked down and he said, "We're not going to let it rain on your speech." In fact, when I first started I said, "Oh no." First line, I got hit by a couple of drops. And I said, "Oh, this is, this is too bad, but we'll go right through it." But the truth is that it stopped immediately. It was amazing. And then it became really sunny, and then I walked off and it poured right after I left. ${ }^{1}$

Trump's first act in office was to make a claim which could easily be proven to be false. All it took was to look at the

\footnotetext{
${ }^{1}$ Sharman, J. (2017): "Donald Trump: All the false claims the 45th President has made since his inauguration," The Independent, January 23, 2017. Verified February 4, 2017: goo.gl/0TyieB

(C) The Author(s) 2019

V. F. Hendricks, M. Vestergaard, Reality Lost, https://doi.org/10.1007/978-3-030-00813-0_4
} 
images from the event to see whether the sun shone or not during his speech.

Another factual question was the size of the crowd. Topping up his speech at Langley, Trump made the crowd size a moot issue:

We had a massive field of people. You saw that. Packed. I get up this morning. I turn on one of the networks and they show an empty field. I say, "Wait a minute. I made a speech. I looked out. The field was ... It looked like a million, a million and a half people." Whatever it was, it was. But it went all the way back to the Washington Monument. ${ }^{2}$

Beyond much doubt, photo material from the inauguration reveals that the crowd did not extend that far. Numbers published by the transportation authorities in Washington, D.C., showed 570.557 registered travels during Trump's inauguration, while 1.1 million travels took place around Obama's first inauguration and 782.000 related to his second inauguration (Fig. 4.1).

This did not keep former White House Press Secretary Sean Spicer from launching a frontal attack on the press accusing it of "reporting erroneously on purpose" with reference to size of the crowd. On January 21, 2017, Spicer stated: "This was the largest audience ever to witness an inauguration, period, both in person and around the globe." ${ }^{3}$ Later that same day, Kellyanne Conway chimed in. On NCB's Meet the Press, this key presidential advisor was confronted with publicly accessible testimonies contradicting Spicer's statement. She defended the statement by arguing it was neither a lie nor a falsehood; rather, Spicer was conveying "alternative facts." On January 23, 2017, Spicer said something to the same effect at a press conference:

Sometimes we [The White House] can disagree with the facts. ${ }^{4}$

\footnotetext{
${ }^{2}$ Ibid.

${ }^{3}$ Ford, M. (2017): “Trump's Press Secretary Falsely Claims" The Atlantic, January 21, 2017. Verified February 4, 2017: goo.gl/HvnFUY.

${ }^{4}$ Smith, D. (2017): "Sean Spicer defends inauguration claim." The Guardian, January 23, 2017. Verified February 4, 2017: goo.gl/djwg7x.
} 


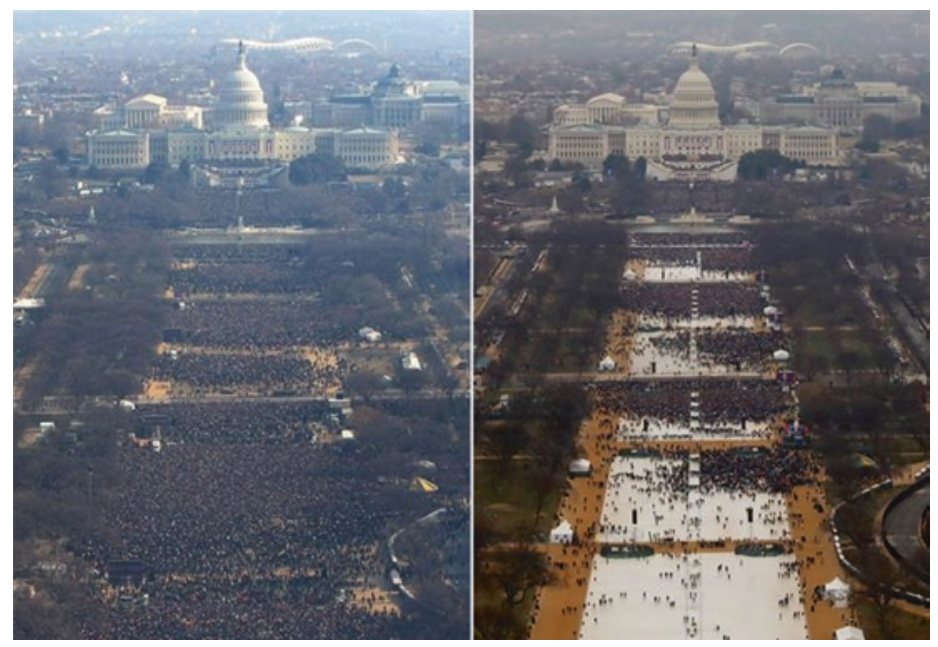

FIG. 4.1. The human crowd gathered at Obama's inauguration in 2009 to the left compared to the one during Trump's inauguration in 2017 on the right.

Leave that one on the screen for a minute. Is it even feasible to deny facts that may be readily verified, propose "alternative facts," or "disagree with the facts?" Logically, the term "alternative facts" makes no sense at all. It breaks the Aristotelian principle of noncontradiction, which probably has been in vogue as long as we have been able to think. As journalist Chuck Todd from NBC made clear to Conway, it is not possible to propose "alternative facts" without either being mistaken or downright lying. Truth be told; Conway did indeed use the term "alternative facts." Apparently that was not what she meant to say. She meant to say Spicer presented "alternative information" as to the number witnessing the inauguration: $2+2=4$ but so does $3+1 .{ }^{5}$ Conway was never

${ }^{5}$ Fitzgerald, S. (2017). "Conway: Spicer was using Alternative Information," Newsmax, 24.01.2017, verified 15.06.2018: https://www. newsmax.com/politics/conway-spicer-alternative-information/2017/ 01/24/id/770122/ 


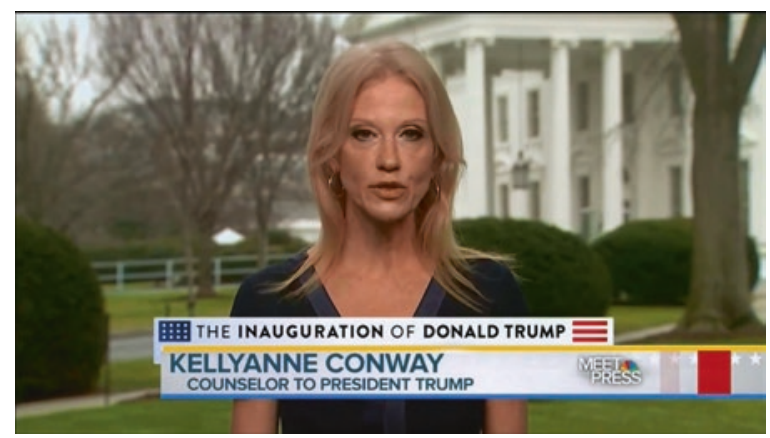

Fig. 4.2. The interview in which Kellyanne Conway introduces "alternative facts".

really able to get that message across. The "alternative facts" stuck in the media perhaps because it seemed indicative of so much else of what was going on. ${ }^{6}$

$\mathrm{Be}$ that as it may, facts are facts. Statements regarding factual matters are either true or false. An alternative claim denying a true statement is simply a false one. You may of course disagree that these are the facts; but disagreeing with facts is to disagree with reality. The statement "the sun is shining" is only true if the sun is actually shining, regardless of specific preference political or otherwise (Fig. 4.2).

Some factual issues are easier to settle than others. Sometimes the facts and truth are difficult to establish. Sometimes they have not been found yet or seem elusive. That's why science and journalism alike keep inquiring.

${ }^{6}$ Pengelly, M. (2017). "Kellyanne Conway: 'alternative facts' was my Oscars La La Land blunder," The Guardian, 04.03.2017, verified 15.06.2018: https://www.theguardian.com/us-news/2017/mar/03/ kellyanne-conway-alternative-facts-mistake-oscars 


\subsection{Truth in Science and Journalism}

The goal of science is to research, understand, and explain the world and the way it works as far as the existing scientific methods will allow. Science seeks truths and knowledge about nature, social conditions, humanity, and technology.

The self-declared goal of science does not fall far from that of journalism. According to the principles stated in the Project for Excellence in Journalism, the primary obligation of journalism is to the truth, but not in an absolute sense. This journalistic truth "is a process that begins with the professional discipline of assembling and verifying facts. Then journalists try to convey a fair and reliable account of their meaning, valid for now, subject to further investigation. Journalists should be as transparent as possible about sources and methods so audiences can make their own assessment of the information." $"$

The world is constantly evolving, and new information may come forth, and thus journalistic truth, just like scientific truth, is tentative. Journalism has to be as transparent as possible when it comes to sources and methods making it possible for readers to make up their own minds about their views and the correctness of the information put in front of them.

Journalism should also be careful to avoid bubble formation and always keep news in proportion but not leave out important details. Journalist's Resource notes that "Journalism is a form of cartography: it creates a map for citizens to navigate society. Inflating events for sensation, neglecting others, stereotyping or being disproportionately negative all make a less reliable map." 8 Sensationalism and poor journalism, as well as pseudoscience, put the reliability of the map under pressure and complicate navigation.

\footnotetext{
${ }^{7}$ Committee of Concerned Journalists: The Principles of Journalism (2006). Verified April 19, 2017: https://journalistsresource.org/tip-sheets/ foundations/principles-of-journalism

${ }^{8}$ Ibid.
} 
"It is what it is," as Robert De Niro says in Heat. The world is what it is. But our interpretations may vary severely as a function of political stances, ideological underpinnings, cultural imprimatur, religious convictions, and so forth. This is not tantamount to saying that there are no such things as facts and truth out there, but we may not have always found them yet. That's the reason why we keep asking questions in journalism and science. The world is recalcitrant ever so often; sometimes it doesn't reveal its secrets to us right away, if ever; other times we ask the wrong questions; sometimes facts catch up with us in surprising ways, forcing us to admit we were initially wrong politically, religiously, journalistically, or scientifically. We are forced to change our minds even if we thought we were right at the outset. It's annoying, but we become the wiser on the way. It is what it is.

\subsection{Information, Misinformation, and Disinformation}

Being informed about something requires having correct, factual information about the subject (Kuklinski et al. 2000). The opposite is not to be uninformed but to be misinformed. If you are uninformed about something, you do not necessarily have a belief about what the facts are. You may, like Socrates, at least know that you know nothing. If on the other hand you are misinformed, you have factually false convictions that you believe to be true. Misinformation misleads citizens, politicians, and journalists. One may misinform others unintentionally by passing on information that is believed to be true but which turns out to be false. If, on the other hand, the misinformation is intended (as hard as that may be to assess or prove), it is disinformation (Søe 2014).

Had the Bush administration itself believed in 2003 that Saddam Hussein commanded functioning weapons of mass destruction ready to be fired, the argument for going to war was a case of misinformation to the public. If, however, the administration did know that Hussein had no such things and 
the misleading was thus intended, it would qualify as a case of disinformation. Intended or not, the consequences were sizeable. A poll from 2015 showed that $41 \%$ of Americans still erroneously believed that active weapons of mass destruction had actually been found in Iraq, ${ }^{9}$ and not, as it were, but old and poisonous yet useless weapon residues. ${ }^{10}$ The same poll explains that $19 \%$ of all Americans found it "totally" or "partially" true that Barack Obama was not a legitimate American citizen. Misinformation and disinformation work. All you need to do is mix in the right doses of false claims and twisted stories with a touch of truth to sugarcoat the pill.

\subsection{True, False, and Everything in Between}

Misinformation is rarely all false. If the misinformation is to have effect, it should not too easily reveal its fraudulence. Misinformation must seem reliable in order to effectively mislead people. Misinformation is therefore often a mixture of something allegedly true; something doubtful, twisted, and undocumented; and downright false information. The composite makes it hard to falsify the misinformation once and for all, as there may just be something to it. This makes it easier for the receiver to swallow and to form or consolidate actual convictions and political beliefs related to the information. When disinformation succeeds, the consequence is that the formation of political views and the votes cast are not based on the available facts but rather on dubious premises.

These reflections lead to the below scale of information quality, where true statements and a variety of misleading

\footnotetext{
${ }^{9}$ Public Mind Poll (2015). "Ignorance, Partisanship Drive False Beliefs about Obama, Iraq." Verified May 10, 2017: http://publicmind.fdu. edu/2015/false/

${ }^{10}$ Chivers, C.J. (2014). "The Secret Casualties of Iraq's Abandoned Chemical Weapons," The New York Times, October 14, 2014. Verified June 10, 2017: https://www.nytimes.com/interactive/2014/10/14/world/ middleeast/us-casualties-of-iraq-chemical-weapons.html?_r=1
} 


\section{Scale of Information Quality}

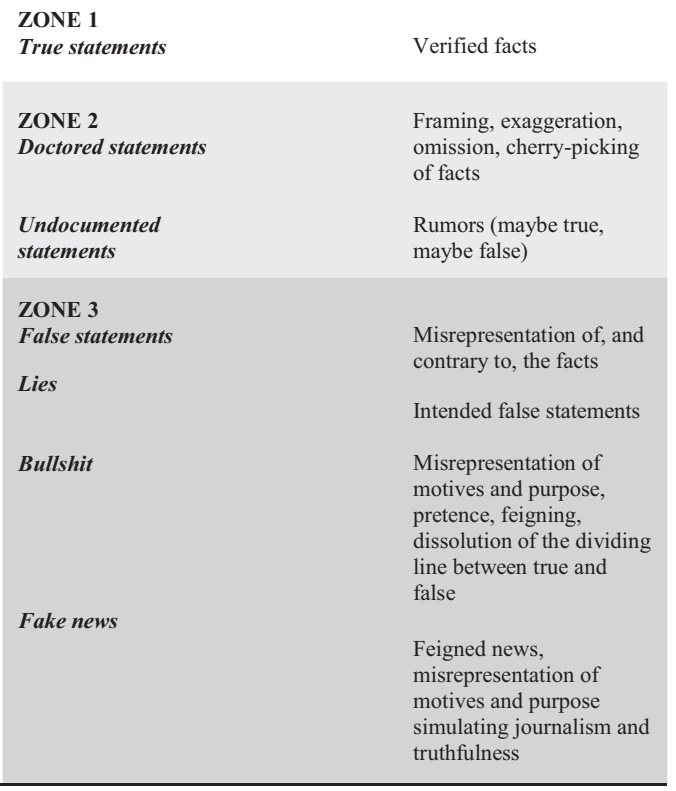

FIG. 4.3. The further down the scale from zones $1-3$, the greater the misinformation.

statements and strategies to undermine the truth are at opposite ends, with all the shades of gray in between (Fig. 4.3).

\subsection{Exaggerations, Omissions, and Cherry Picking}

Even though there are no direct false claims involved in a biased presentation of a case, it may result in a twisted perception of reality. Setting the agenda (see Chap. 2) is not only about which cases get attention but also how they are framed and presented. In attention economics, framing may be 


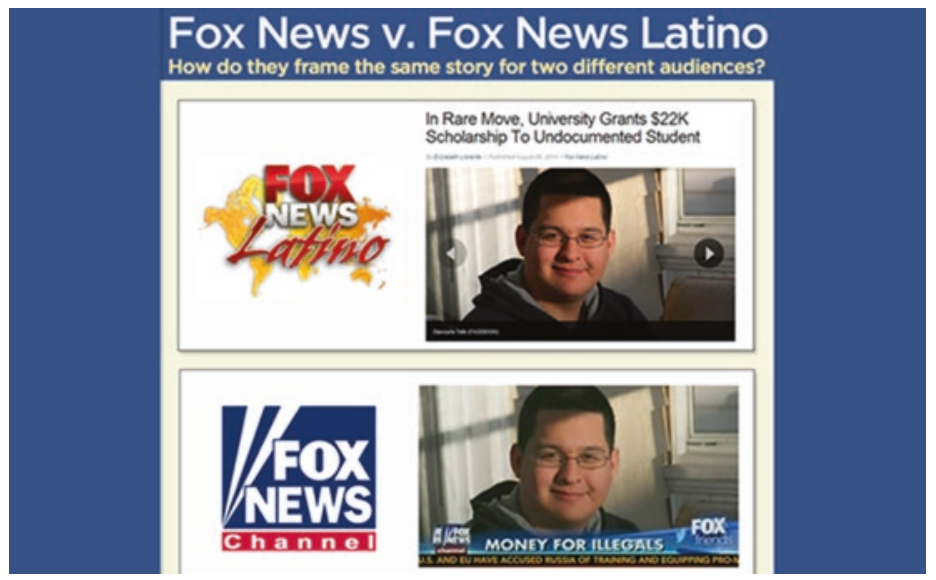

Fig. 4.4. Fox frames two identical news stories differently for two different audience segments. For the Spanish-speaking segment, the more neutral word "undocumented" is used to describe the student, while the main channel Fox News uses the negative term "illegals". (Parker, J. (2014). "Fox News and Fox News Latino Cover the Same Story, Hilarity Ensues," Addicting Info, August 8, 2014. Verified June 10, 2017: http://addictinginfo.com/2014/08/08/fox-news-and-foxnews-latino-cover-the-same-story-hilarity-ensues/?fb_comment_id= 593132244141420_593734977414480\#f2dbfa4a983dc36).

understood as a question of which aspects of a given case that get attention, at the cost of others (Fig. 4.4).

The same goes for the way in which a news story is presented. If, say, the topic is unemployment, the reporter may choose to contact an unemployed person talking about all job applications sent in vain. The reporter may on the other hand also reach out to an employer who is having trouble finding employees. Depending on focus, the same topic may be cast either as a question of lazy and greedy, unemployed "villains" or the systemic conditions whose "victims" are the unemployed. If the framing is massively and systematically leaning in one direction, then the result is an unbalanced coverage and presentation of information that may indeed be misleading. If only one side of things is presented, it may happen at 
the cost of other perspectives and facts that are part of the whole story and the complete picture. Notwithstanding, it also serves as a problem to always insist that there are two sides to everything and that they are necessarily equally compelling. Fifty/fifty journalism may be based on a misperception of the ideals of balance and objectivity (Korsgaard 2017). An extreme case would be to confront a flat Earth believer with a scientist presenting the idea that the sun is at the center of things and treat the two as bona fide equal, cosmological positions. The fact that people have a right to their opinion does not mean that all opinions are equally cogent. Besides, although you have a right to your own opinions, you don't have a right to your own facts Daniel Moynihan once instructed us.

When the angle is exaggerated or the framing extreme, the result may be sins of omission. If you insist on focusing on the approximately $9 \%$ of youth in Denmark that have been sentenced at least for violating the criminal code, then you might leave undone the bulk of youth being law-abiding citizens. Or if the majority of stories published about Muslims focus exclusively on the small minority committing crimes and/or supporting a radical or version of Islam, it generates a misleading and nonrepresentative picture of the real world and its risks. It may generate lots of clicks but also a great deal of indignation, fear, and polarization.

Akin to sharpening the frames is cherry picking: You pick exactly the cherries from the tree suiting the case in point but ignore or suppress others. In politics, it means omitting the facts not fitting the program, perspective, or point of view. Facts become something to use or ignore according to needs. It undermines the conditions for evidence-informed politics.

Doctoring of statements may also occur by dint of misrepresentation. Only about an hour after Nigel Farage, the leader of the British campaign for leaving the European Union, had proclaimed victory in the Brexit vote, he had to admit to the TV cameras that a crucial number his campaign had been based on was incorrect. The leave campaign had promised to add 350 million pounds to public health services every week 


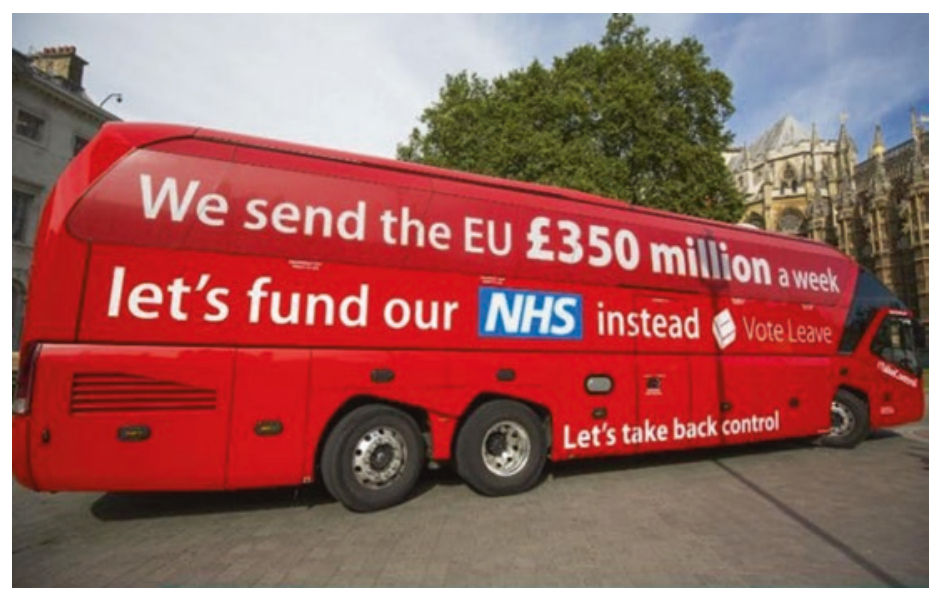

FIg. 4.5. A Brexit campaign bus with an election promise that could not come to pass.

if the British exit came to pass. Farage rejected his own campaign promise as a "mistake" when confronted with it. It was a distortion of the truth to talk about this as a mere "mistake" when, really, even campaign busses in the UK had references on them to this political promise that could not be realized (Fig. 4.5).

\subsection{Rumors, Belief Echoes, and Fact Checking}

Undocumented rumors may be true or false. Sometimes, there is something to them and sometimes not. Nonetheless, rumors may have an enormous influence on people's perception of a situation or a person, including a politician. The same goes even if the rumors have been debunked exactly as make-believe. That makes rumor mongering and smearing campaigns efficient misinformation tactics carried into the world by belief echoes. 
The term belief echo applies to the phenomenon that, even after an alleged political scandal or rumor has been put to rest as fraudulent and established to be false, the belief echo still has an influence on people's perception of the person at the center of the rumor or the scandal (Thorson 2016). An unfounded, negative rumor about a politician which has been fact checked and falsified beyond any reasonable doubt may still damage the politician's name and fame. Belief echoes unfortunately show how fact checking has limited effect or perhaps sometimes even make matters worse. Fact check needs to reiterate the false claim, which in and by itself makes the belief echoes stronger. And even if the fact check is taken at face value, the rumor still damages the reputation of its subjects.

The US fact checking website Politifact run by the Tampa Bay Times has won a Pulitzer Prize for its work. They keep an eye on how different politicians and the media do when it comes to dealing with the truth (Fig. 4.6).

Undoubtedly, such reckoning must adjust for political bias, the media outlet's editorial policies and other journalistic inclinations, the reliability of sources, and other contingencies. Even so, the reckoning is rather thought-provoking. If you compare Clinton and Trump during the election season in 2016, Clinton was ahead when it came to the truthfulness of her statements (Figs. 4.7a and 4.7b), even though scoring more than a third as false statements is hardly impressive (Fig. 4.8).

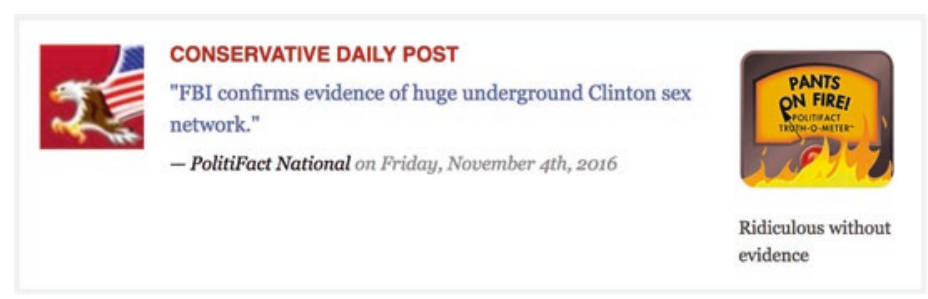

FIg. 4.6. Politifact's assessment of the Conservative Daily Post's story claiming that the Clintons were part of a sex network. 


\section{True}

Mostly True

Half True

Mostly False

False

Pants on Fire

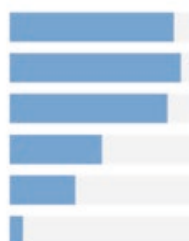

FIG. 4.7a. Hillary Clinton's score board on true/false statements, summed on April 10, 2017, by Politifact.

\begin{tabular}{l|r} 
True & $16(4 \%)$ \\
Mostly True & $48(12 \%)$ \\
Half True & $55(14 \%)$ \\
Mostly False & $77(20 \%)$ \\
False & $127(33 \%)$ \\
Pants on Fire & $63(16 \%)$
\end{tabular}

FIG. 4.7b. Donald Trump's score board on true/false statements, summed on April 10, 2017, by Politifact.

\section{HILLARY CLINTON}

"We are now, for the first time ever, energy independent."

- PolitiFact National on Tuesday, October 1uth, 2016

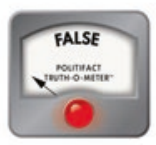

On track, but not there yet

FIG. 4.8. A statement from Hillary Clinton at the nethermost end of the truth value scale.

Obviously, this sort of arithmetic does not mean much if the voters have no faith at all in the fact checkers. A study from September 2016 shows that only 29\% of American voters trust fact checks and the media outlets producing 
them. ${ }^{11}$ In a political landscape of distrust, lies may be useful tactics even if unveiled.

\subsection{Lies and Bullshit}

Exaggerations, misrepresentations, omissions, cherry picking, and rumors may all, alone or combined, comprise bendings of the truth. Yet more undermining are lies, bullshit (Frankfurt 2005), and fake news.

Lies and bullshit are both attempts of deception. There is a difference related to the deceit: the liar tries to deceive by consciously misrepresenting facts. The lie has as its purpose to induce beliefs in the person victim of the lie, thus tampering with subject's perception of the truth.

Bullshit, on the other hand, tries to deceive someone by misrepresenting the sender's real intentions, motives, and purpose. The bullshit's goal is not necessarily to get people to believe the content of what is being said. It may be to make people act in a certain way or to try and get away with something without anyone getting smart about the intention. You may, for instance, bullshit by presenting heaps of irrelevant but factually correct information to take attention away from the real subject. This may furnish the impression that you are trying your best to answer the question, while in reality all you are doing is buying time and avoiding answering.

The liar acknowledges the distinction between true and false but tries to hide the truth. In fact a lie cannot be defined without observing such a distinction. The bullshitter totally ignores the question of truth/false and facts. Bullshit is a bigger threat to truth than lies (Frankfurt 2005: p. 61). Bullshit is of a toxic nature. Stocks of successful bullshit may add to dis-

\footnotetext{
${ }^{11}$ Rasmussen Reports (2016): "Voters Don't Trust Media Fact-Checking," September 30. Verified February 5, 2017: http://www.rasmussenreports. com/public_content/politics/general_politics/september_2016/ voters_don_t_trust_media_fact_checking
} 
solving the distinction between true and false. Simulation may have that effect - and bullshit consists in feigning, simulating, or pretending to be or do something other than what you really are or do.

The bullshitter is faking things. ${ }^{12}$

The bullshitter fakes something. That is also what fake news stories do. They fake journalism and news coverage and may be coined "feigned news."

\subsection{Fake News as Feigned News}

Fake news has been described as "invented material that has been cleverly manipulated so as to come across as reliable, journalistic reporting that may easily be spread online to a large audience that is willing to believe the stories and spread the message." 13

It must be noted, however, that fake news is not exclusively an online phenomenon. It has existed since long before the invention of the Internet. Neither is fake news inevitably a lie. Fake news can come in the form of an outright lie that tries to portray an intentionally false story as being true. But often, fake news qualifies as being bullshit where the intention is not so much to have people believe an untrue story. Rather, by means of fake news, people are being manipulated to a certain stance or behavior. Even if fake news often consists of false or undocumented claims, distortions, misrepresentations, and so forth, the defining feature of fake news is not the fact that it is bogus. It simulates to be journalism and truth-seeking, while its goal is something entirely different. By posing as real news, fake news may pretend to have enlightenment or truth as its end goal, while really it has a

\footnotetext{
${ }^{12}$ Frankfurt (2005: p. 48).

${ }^{13}$ Holan, A.D. (2016). "2016: Lie of the Year: Fake News," Politifact, December 13, 2016. Verified April 7, 2017: http://www.politifact.com/ truth-o-meter/article/2016/dec/13/2016-lie-year-fake-news/
} 
political or monetary goal aimed for by attention reaping. This goal is kept hidden from the audience. The seeming reliability is enhanced by website addresses that sound real often supplemented with further "testimonials" like pictures and video footage more or less cleverly manipulated.

Four main reasons to foster fake news and put these pseudo journalistic products onto the market may be isolated:

1. Fun/trolling

2. Web traffic/money

3. Marketing/sales

4. Propaganda/power struggle

\subsubsection{For Fun/Trolling}

"Real news that you can't get from the mainstream media" is the tagline on the news portal, the Underground Report, that deals in feigned news stories such as Michelle Obama having undergone a sex-change operation, Bernie Sanders having Russian connections dating back to the 1960s, and CNN having connections to the Islamic State. The news portal was started on February 21, 2017, by a man named James McDaniel, living in Costa Rica. The website was really a joke or commentary aimed at demonstrating how naïve and gullible Internet users may be. Within a couple of weeks, UndergroundNewsReport.com got more than one million views. McDaniel's fictions, fabrications, and fantasies that catered primarily to a Trump-friendly audience were read and shared widely and received thousands of comments, while only a handful among the audience expressed critical views on the legitimacy of the stories. Three weeks after launching the site, McDaniel made it clear to his readers that is was all a joke. He added: "I was startled that in today's world, so many could be so willfully ignorant. It's truly a frightening time when a group of people screaming, "FAKE NEWS!" at the top of their lungs, live, eat and sleep 
falsehoods." 14 The website is no longer being updated and stands as a reminder of how easy it is to influence people with fake news.

\subsubsection{Web Traffic/Money}

A great deal of money may also be made on fake news. Between August and November 2016, "Boris" from Veles in the Eastern European Macedonia earned upward of 16,000 USD on his two websites producing fake news in favor of Trump. Considering that the average wages in Macedonia is 371 dollars a month, Boris decided to drop out of high school in favor of his new occupation of circulating feigned news, even though he, like so many others that partook in this new type of business venture, did not care if Trump won or lost the election. It was merely a question of raising the necessary funds for new cell phones, watches, cars, and drinks at the bar. ${ }^{15}$ It was of little interest to the producers of the fake news whether or not the readers believed the stories. Fake news served merely as clickbait. It was digitally produced bullshit with the simple purpose of getting people to invest their click and allocate their attention, which in turn is sold to advertisers. Platforms like Google and Facebook have created strong economic incentives for producing and spreading fake news on this business model. There is money to be made on the market for misinformation. As long as that is the case, it will be difficult to stem the tide of misleading rumors, lies, bullshit, and fake news.

\footnotetext{
${ }^{14}$ Gillin, J. (2017). "Fake News website starts as a joke, gains one million views within 2 weeks," Politifact, March 9, 2017. Verified May 2, 2017: http://www.politifact.com/punditfact/article/2017/mar/09/fake-newswebsite-starts-joke-gains-1-million-view/

${ }^{15}$ Subramanian, S. (2017). "Inside the Macedonian Fake-News Complex," Wired, February 15, 2017. Verified April 10, 2017: https://www.wired. com/2017/02/veles-macedonia-fake-news/
} 


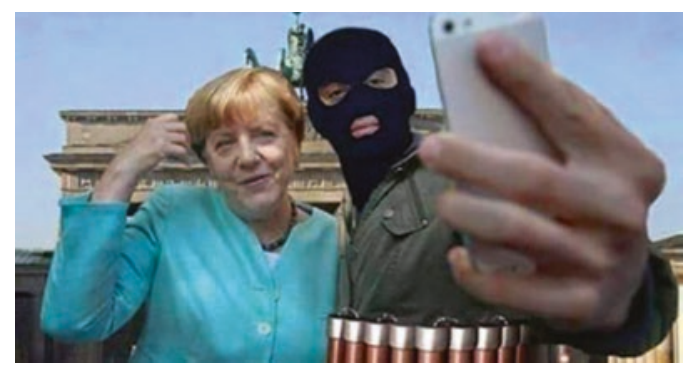

FIg. 4.9. A manipulated photo of Angela Merkel supposedly posing for a selfie together with a suspected terrorist in front of Brandenburger Tor in Berlin.

\subsubsection{Marketing/Sales}

In the market for attention, the actual costumer is the advertising or marketing industry paying for clicks. The marketing industry is quite familiar with the strategy of hiding real intentions by imitating journalistic products. It is called native advertising in the industry. The US-American advertising tycoon David Ogilvy (1911-1999), also known under the epithet The Father of Advertising, reveals the trick and encourages advertisements to resemble real news stories and journalism:

It has been found that the less an advertisement looks like an advertisement, and the more it looks like an editorial, the more readers stop, look and read. Therefore, study the graphics used by editors and imitate them. Study the graphics used in advertisements, and avoid them. ${ }^{16}$

The advice has been taken in by the industry, especially in the USA. Ready-made advertisement products dressed up as actual news reports, called video news release (VNR), are

\footnotetext{
${ }^{16}$ Pollitt, C. (2014). "Advertorials in the Age of Content Marketing and Promotion," Relevance, November 10th 2014. Verified November 26th 2017: https://www.relevance.com/advertorials-in-the-age-of-contentmarketing-and-promotion/
} 
being transmitted undifferentiated during newscasts without being declared as marketing. ${ }^{17}$ The same trend may be observed in newspapers containing ads that blend in smoothly with the overall layout of the rest of the paper. This way, marketing is benefitting from and feeding on the credibility that traditionally has been associated with news coverage and journalism. When advertisement is not declared as such, they can rightfully be labeled fake news, even if they do not contain any false statements (Fig. 4.11).

Even though advertisement and marketing industry has lately been making much use of simulated journalism, the industry did not invent fake news. The method of faking journalism is inspired by methods used in war propaganda and power politics. The production of fake news is as old as the printed press. It was originally used as soft power in conflicts, power struggles, and warfare. ${ }^{18}$

\subsubsection{Propaganda/Power Struggle}

In 1782 during the US-American War of Independence, Benjamin Franklin was in Paris to negotiate peace between England and the USA. During his stay in Paris, he published a fake version of the actual newspaper the Boston Independent Chronicle. The fake publication contained a fictional letter that incorporated a false report on the slaughtering and scalping of more than 700 individuals, including peasants, women, children, and infants. The invented incident had supposedly been carried out by the indigenous population who

\footnotetext{
${ }^{17}$ Farsetta, D. \& Price, D. (2006). "Fake TV News: Widespread and Undisclosed." Center for Media and Democracy, 16.03.2006. Verified November 26th 2017:

${ }^{18}$ Soll, J. (2016). "The Long and Brutal History of Fake News," Politico Magazine, December 18th 2017, verified November 28th 2017: https:// www.politico.com/magazine/story/2016/12/fake-news-history-longviolent-214535
} 


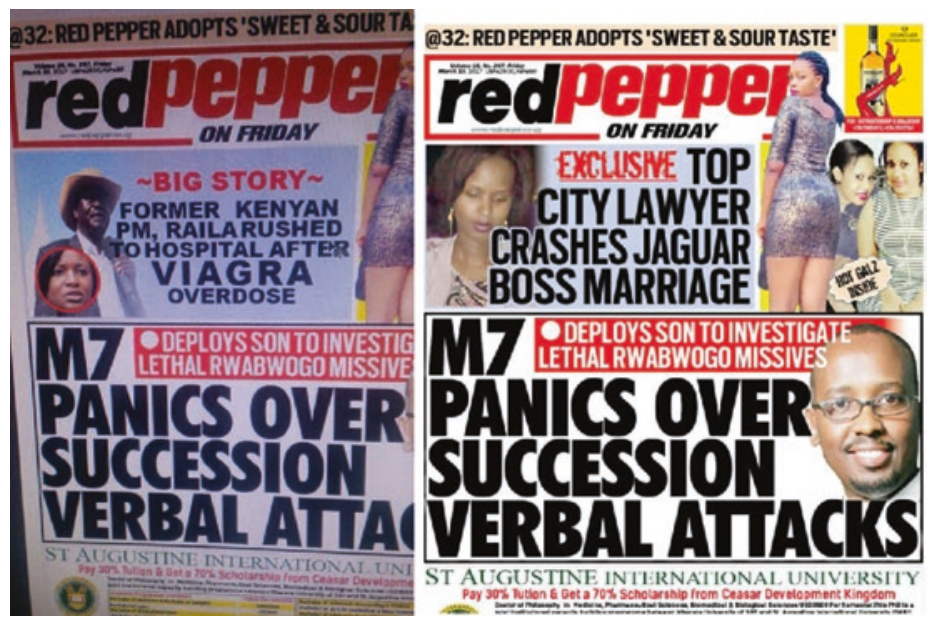

FIG. 4.10. An example of the fake news ahead of Kenya's elections 2017. Doctored front page of the Ugandan tabloid Red Pepper on the left, the real one on the right.

acted in accord with the command of the British army. ${ }^{19}$ To make the false copy credible, the typography of the actual newspaper was imitated completely with fake ads and announcements (Fig. 4.13).

By means of fake news, Franklin intended to impact public opinion in England and Europe as opposed to merely selling papers to readers and their attention to advertisers. By spreading the story with the help of printed media, the story was envisioned to divide Europe internally swaying the British population together with the broader European public against the war and the King. ${ }^{20}$ If successful, the American

\footnotetext{
${ }^{19}$ Franklin, B. (1782). "Supplement to the Boston Independent Chronicle," [before 22 April 1782], Founders Online, National Archives, verifizert 28.11.2017: http://founders.archives.gov/documents/ Franklin/01-37-02-0132

${ }^{20}$ Berry, J. (2017). "The economic efficiency of fake news," Oxford University Press's Academic Insights for the Thinking World, January 17th 2017. Verified November 28th 2017: https://blog.oup.com/2017/01/ economic-efficiency-fake-news/
} 
position in the war would be strengthened as to the geopolitical power struggle and the specific negotiations for peace.

Dispersing fake news and disinformation as propaganda is about gaining political power and advantages. Advantages entail distrust, internal division and confusion on the side of the opponent, and combativeness, loyalty, and support in your own camp. Fake news can be a soft yet powerful weapon of propaganda in conflicts and wars.

Fake news, partially or wholly constructed stories, false exposure of corruption and fraud or a politician's supposed affiliation to a sinister conspiracy, and so on may entail that the victim of the untruthfulness is considered being corrupt, immoral, or even evil. The same strategy of discrediting and delegitimization may be used against inconvenient journalists and media or even dehumanization whole groups. Disinformation contributes to conflict, polarization, and spiteful feelings potentially threatening to civilized and constructive political debate and social cohesion. Divide and conquer is a universal motto motivating opponents on the international geopolitical scene as well as internal agents on both ends of the political spectrum.

The aim of politically motivated fake news is not exclusively to have citizens, journalists, and politicians believe a lie like in Franklin's case above. Mis- and disinformation may be produced and dispersed to confuse or befuddle the public. Russia has been accused of having used precisely this kind of strategy by spreading propaganda domestically and by dispersing disinformation geopolitically. It is contended that Russia is responsible for constructing and putting into circulation conflicting narratives on traditional and social media creating chaos and confusion. In the end, no one can tell truth from falsehoods and the factual from the fabricated..$^{21}$

\footnotetext{
${ }^{21}$ Mariani, M. (2017). "Is Trump's Chaos Tornado a move from the Kremlin's Plauybook?", Vanity Fair, 28.03.2017, verified 17.06.2018: https://www.vanityfair.com/news/2017/03/is-trumps-chaos-a-move-fromthe-kremlins-playbook
} 
Regardless of the amount of dis- and misinformation actually originating in Russia and of how well organized it is, it may be said with more certainty that dis- and misinformation have caused confusion and disorientation in the USA. According to a survey conducted by the Pew Research Center, $63 \%$ of the American respondents answered that the constant stream of fake news during the election created $a$ great deal of confusion about what was actually true and what was not. $24 \%$ experienced some confusion, and $11 \%$ were only mildly confused or not confused at all. ${ }^{22}$

When mis- and disinformation reach this level, it is a threat to democracy and security. The international security conference held in Munich 2017 arrives at the same conclusion. The final report with the telling title "Post-Truth, Post-West, PostOrder" 23 identifies the loss of trust in the media and in politicians as the main threat from fake news and disinformation. Mistrust in and delegitimization of journalists and politicians make citizens even more suspicious susceptible to fake news (Colombo and Magri 2017). This undermines trust and legitimacy even more, initializing a vicious circle threatening democracy itself.

Braden R. Allenby, professor at Arizona State University, summarizes aptly how fake news and misleading narratives may be used as weapons on the national as well as the international scene. He defines weaponized narratives as "the use of information and communication technologies, services, and tools to create and spread stories intended to subvert and undermine an adversary's institutions, identity, and civilization, and it operates by sowing and exacerbating complexity, confusion, and political and social schisms." ${ }^{24}$

\footnotetext{
${ }^{22}$ Barthel, M, Mitchell, A., \& Holcomb, J. (2016). "Many Americans Believe Fake News Is Sowing Confusion," Pew Research Center, 05.12.2016, verified 17.06.2018: http://www.journalism.org/2016/12/15/ many-americans-believe-fake-news-is-sowing-confusion/

${ }^{23}$ Munich Security Report (2017), verified 04.04.2017: report2017.securityconference.de/

${ }^{24}$ Allenby, B., R. (2017). "The Age of Weaponized Narrative, or, Where Have You Gone, Walter Cronkite?" Issues in Science and Technology 33,
} 


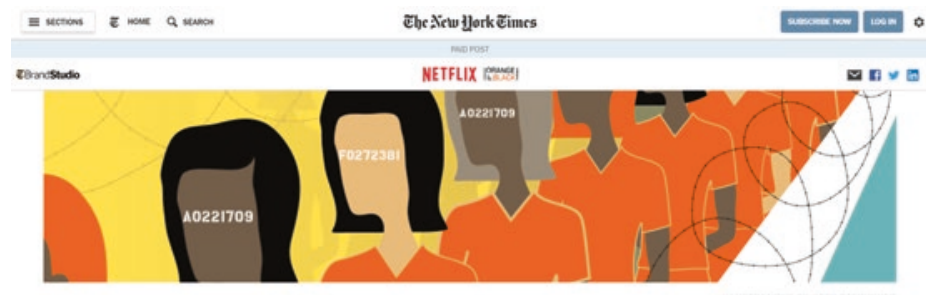

Over the past three decades, the number of women serving time in American prisons has increased more than eightfold.

Today, some 15,000 are held in federal custody and an addtional 100,000 are betind bars in local jals. That

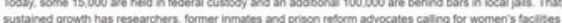

FIG. 4.11. Native advertising that is explicitly declared as such. This ad draws attention to the TV series "Orange Is the New Black." The ad is from The New York Times in 2014. Besides containing factually correct information about female inmates and their conditions in prison in the USA, the ad simulates the layout and the style of editorials.

Several of the fake stories that circulated online during the German election in 2017 affirm Allenby's definition of weaponized narratives, regardless of the actual intention and origin of the fake stories in question. During the election in Germany as well as during the US-American election, stories were highly polarizing; they fostered suspicion. Those conspiring narratives are a perfect tools for fueling division, subversion, and distrust.

\subsubsection{Merkel the Supervillain}

In Europe, fake news has also made its way into the media. For instance, stories were run about German Chancellor Angela Merkel not only taking selfies with terrorists (Fig. 4.9) but also being mentally disturbed and simultaneously secretly

no. 4, Summer 2017. Verified December 1st 2017: http://issues.org/33-4/ the-age-of-weaponized-narrative-or-where-have-you-gone-waltercronkite/ 
Merkill gratuliert zur Kinderehe. Wie gestört ist diese Person.

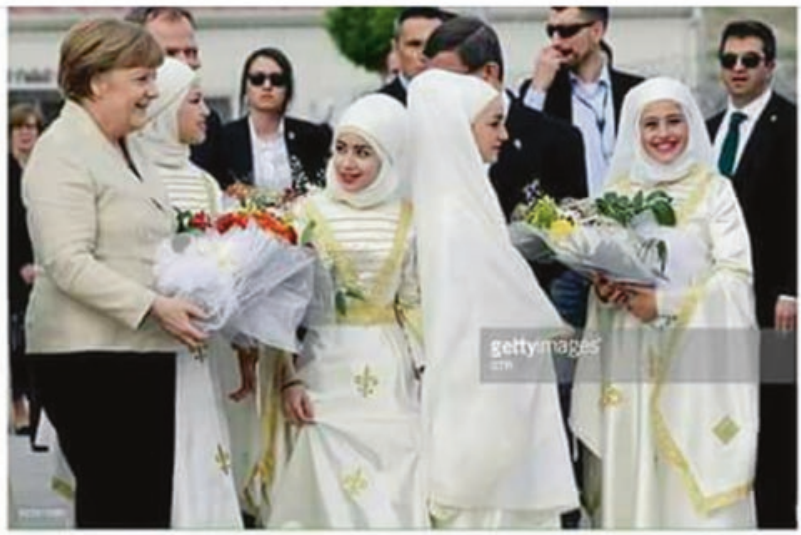

Dieses Bild würde Merkel am liebsten verbieten lassen!

It Like $\rightarrow$ Share </ Embed
சலஃ 151

FIG. 4.12. Angela Merkel greeting Muslim child brides according to the tweet.

running big German media outlets such as the public broadcasting company ZDF like a puppet master (Fig. 4.11).

Most misinformation centered on Angela Merkel's open door policy of refugees fleeing wars in Syria and other countries in late 2015. According to the UN, no other country in the world received as many requests for asylum during this period as Germany, which ended up welcoming more than a million refugees. This has sparked a backlash against Merkel's policy feeding misinformation predominantly related to refugees, migrants, Muslims, Islam, and rumors about refugees committing crimes or being granted excessive welfare bene- 
fits. Some stories are generated locally; some were be tracked back to Russian trolls. ${ }^{25}$

One circulated fake news story that gained some momentum was a picture of Chancellor Merkel flanked by several young women dressed in white. The caption text is "Merkel wünscht den kinderbräuten alles gute" suggesting Merkel wishing Muslim child brides good riddance (Fig. 4.12).

The true story about the picture is that it was taken while Merkel visited a refugee camp in Turkey in April 2016, and the women dressed up in their finest white outfits greeting her welcome-nothing to do with child brides and wedding gowns. But this fact did not stand much of chance at peak of the fairly intense online circulation. Nevertheless, overall it seems that Germany was largely spared much fake news and misinformation during the election.

While Germany got off relatively easy, Kenya was hit hard with fake news campaigns, and scores of misinformation were detected during the election cycle in $2017 .{ }^{26}$ According to a survey from Portland and Geo Poll, they found that $90 \%$ of the respondents had seen or heard false reports, while $87 \%$ of the respondents reporting deliberately false or downright fake news stories (Fig. 4.10). ${ }^{27}$

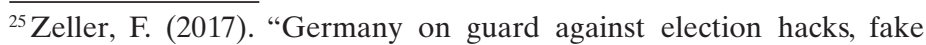
news," Mail \& Guardian, 21.09.2017, verified 17.11.2017: https://mg.co.za/ article/2017-09-21-germany-on-guard-against-election-hacks-fake-news ${ }^{26}$ Kamau, A. (2017). "Deaths, defections and deceit: How Kenya's fake news spreads," African Arguments, 02.08.2017, verified 15.06.2018: http:// africanarguments.org/2017/08/02/deaths-defections-and-deceithow-kenyas-fake-news-spreads/

${ }^{27}$ Portland and Geo Poll, 19.07.2017, verified 15.06.2018: https://portlandcommunications.com/pdf/News-Release-The-Reality-of-Fake-News-inKenya.pdf
} 
Numb. 705 .

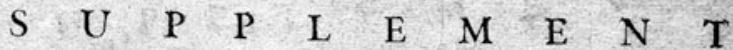 \\ TOTHE BOSTON}

\section{INDEPENDENT CHR ONICLE.}

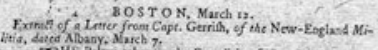

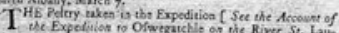

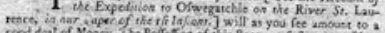

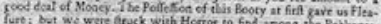

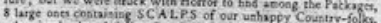

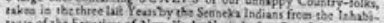

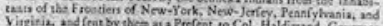

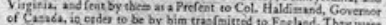

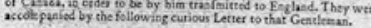

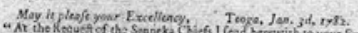
elliency, vider the Cure of

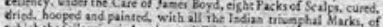

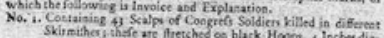

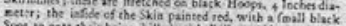

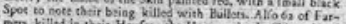

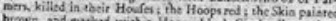

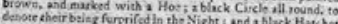

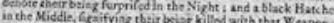

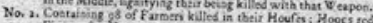

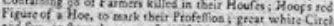
ind Sur, to heve they were furperifed is the Dey-tines a tin rid Foes, to thew thendood upon their. Defince, and died

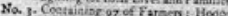

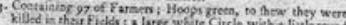
Nark oajt for the Sws, to Dew that is was in whe Day row

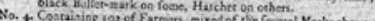
+ Cosaining yoz of Faroen, mixod of thie fiveral Marky above; ing of Prifosed burnt allive, after being foalged, their $\mathrm{N}_{2}$ ils

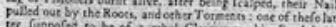
ter fuppoied to be of a mot Clergyan, his Bland belie

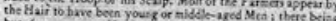

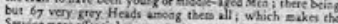

No. 5. Cooranger 88 Srajps of Women; Hair long, braided is theloyellow Grow, to wew they were Nothers; Hoops blut; Skin of Triumph, the Tear or Griefiocaf oned to the is if by way a Black f alping Knife or Hachet at tho Hortom, to matk thet

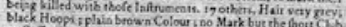

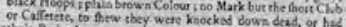

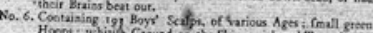
Hoopt; whing Ground on ithe Skis, with red Teas is the Middle, and black Ballet-anaks, Knifs, Hasther, or Club, as

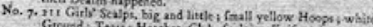

No. 8. This Package in Mixture of all the Varietien above-mention'd, to the Number of $u$; ; with a Box of Birch Bark, contailing,

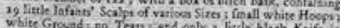
white Grounds no Tewr and only a litde black Knife is

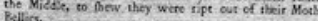

Eith thefe Packs, the Chites fend to your Excellescy the folloging

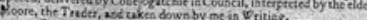

Fethe.

Fefesd you herewith many Scalpow that yow may fee we are noc ide. Friens. Fertich

We wiah you ro frod chefe Scalps over the Vater to the great Kiag.

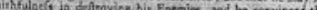
inced that lit

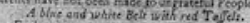

Artend to what 1 as pose going to fay : it is a Matrer of much

thet bite not fcratcls: we could play wich the foflyz we frars not whige they could do to ut. Bot Dow their Hodies are becoene big

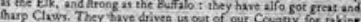

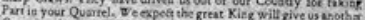
Coverty, that our Chisdres ayy live ifter us, add be his Friendd and Childers, as we are. Say this for un to the great King. To enforce if A great whive Delt wheb blor Tagdi.

We have ondy to fay farther that your Traden exaet soce thas eyct for

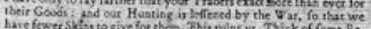

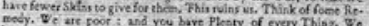
moty. We are poor : and you bave Pleaty of eveyy This\%. Wo chets : butwe alfo want Shints ans Blak =kte. A Linite to tire Eetio.

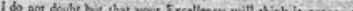

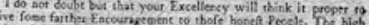

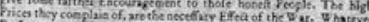
prescests may be fent for then through my Hads, Mall be diftribuated th Fruderese and Fidelity. Thave ik: Honcour of being Your Excellency'm mol obedienc And moA humble Servant
AAMES CRAUF ORDF

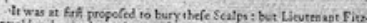

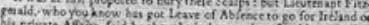

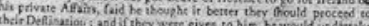

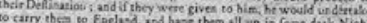

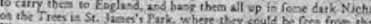

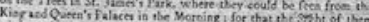

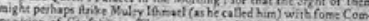

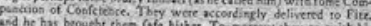

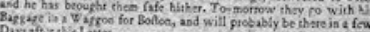

$$
\begin{aligned}
& \text { Iam, SCE. SM UEL GERRISH. } \\
& \text { BOSTON, Match zO. }
\end{aligned}
$$
Mostay lat anived here bieuterant Fitzensld abovenentiosed

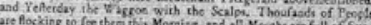
craticas. Fixing then th the Morrieg, and all Mosats are foll of fx:

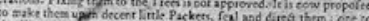
the King, coentining a Suiple of wery Sore for bis Mefrow i one to

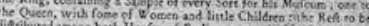

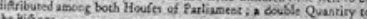
At biacops

A convenient Tan-Yard, lying in Medfield,

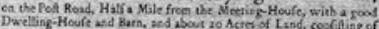

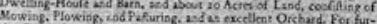

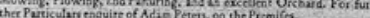
A TOBESOLD,

A large Tract of L A N D, lying partly in

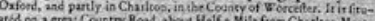
ated od a great Country Road, about Half a Milis ficm Chartoos MreetGr-Houle, and is ca fable of making i Nuaber of fae Sertemetect. Foe muel Darforts, of Boiton.

All Perfons indebted to, or that have any

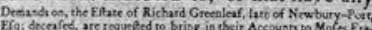

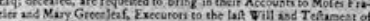
the deceafed, for an in mediate Setulement.

Affmall new Brick H O U'S E, two Rocms ca a Floog at the South Part of the Town,-Enquire of the Printer. Strayed or ftolen from the Subferiber,

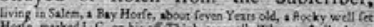

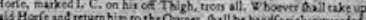
HENRY WHITE.

Fig. 4.13. The feigned news story with Benjamin Franklin as its author in the fake newspaper from 1782. (Onion, R. (2015). "The Atrocity Propaganda Ben Franklin Circulated to Sway Public Opinion in America's Favor," Slate, 01.07.2015, verified 17.06.2018: http://www.slate.com/blogs/the_vault/2015/07/01/history_of_benjamin_franklin_diplomacy_propaganda_newspaper_with_stories. html). 


\subsection{Information Whitewashing}

The Internet and social media are potent beds for fake news to spread. The Internet gives access to a potentially sizable audience, the investment to get your say is limited, and there is little gatekeeping: great conditions for anything to spread, whether it is true, false, misrepresentation and rumors, lies, or bullshit and feigned news. With befitting software, it is easy and cheap to manipulate pictures digitally. With the emergence of deep fake videos and new methods to manipulate audio, simulating the real thing is only going to get ever more palpable. Add to this the automatized spreading of misinformation through robots. "Bots" are programs that may look like a human Twitter user, for instance, but spread information automatically through the network.

Emilio Ferrera, computer scientist at University of Southern California, estimates that approximately $15 \%$ of all Twitter profiles are bots. Among Twitter profiles, the number of fake followers or bots differs considerably. According to a Twitter Audit evaluation from December 2017, 43\% of Donald Trump's followers on Twitter (@realDonaldTrump) are fake users being bots. ${ }^{28}$ By means of fake followers, the impression may be instilled that the support of a candidate, the anger toward an opponent, or the interest in a news story is bigger than it actually is. A story seems more credible the bigger its circulation and the higher the attention rate it receives. A story being read and shared by many people may work as a social proof for the quality of the story and its legitimacy. If the social proof is strong enough to trump critical reflection, you may end up doing what you are doing or reading and believing what you are reading just because you believe others are doing the same (Hendricks and Hansen 2016). Such social psychological lemming effects or information cascades are bots able to contribute and reinforce.

\footnotetext{
${ }^{28}$ Twitter Audit Report “@realDonaldTrump“ 03.12.2017, verified 03.12.2017: https://www.twitteraudit.com/realDonaldTrump
} 
The more misinformation is circulated and repeated and finds its way to new platforms and media houses for both the authorized and the alternative press, the more whitewashed the misinformation becomes. There are examples of stories made up for fun or as satire that with time have become whitewashed through circulation and shared as news stories, in order to later be shared or referred to in books as examples of polarized party politics or geopolitical misinformation.

The Internet, digitalization, and social media have created an environment for debate and opinion formation in which news products far from being prime flourish just as well as documented truthful news stories (Moncanu et al. 2015). When it comes to competing for attention, truth does not outweigh false, lies, and bullshit (Vosoughi et al. 2018). Whatever is true is not necessarily viral, and whatever is viral is not necessarily true. In a free and unregulated market for information and news, the inferior news products are not automatically weeded out. In opposition hereto is an overly optimistic rationale of the marketplace of ideas in which truthful information will without any interference and censorship outcompete untruthful ideas in public sphere:

The ideas and opinions compete with one another, and we have the opportunity to test all of them, weighing one against the other. As rational consumers of ideas, we choose the "best" among them. In the same way that "bad" products naturally get pushed out of the market because of the lack of demand for them and "good" products thrive because they satisfy a demand, so also "good" ideas prevail in the marketplace and "bad" ones are weeded out in due course. ${ }^{29}$

A precondition for the ability of the marketplace of ideas to efficiently sort the good information products from the bad ones is the assumption that the consumers of ideas are rational. That they clearheadedly weigh ideas against each other and evaluate according to available evidence as rational agents would. Rational agents base opinions on facts and sober reasoning period. But we are not rational agents or

${ }^{29}$ Gordon (1997). 
exemplars of homo economicus. We are humans-and humans are affective beings motivated by emotions more than reason (Hume 1739; Freud 1917; Haidt 2001). This makes us susceptible to all kinds of trickery, deceit, and emotional manipulation as well as resistant to inconvenient facts. Psychological mechanisms are part of the picture. We believe what we want to believe.

Open Access This chapter is licensed under the terms of the Creative Commons Attribution 4.0 International License (http://creativecommons.org/licenses/by/4.0/), which permits use, sharing, adaptation, distribution and reproduction in any medium or format, as long as you give appropriate credit to the original author(s) and the source, provide a link to the Creative Commons license and indicate if changes were made.

The images or other third party material in this chapter are included in the chapter's Creative Commons license, unless indicated otherwise in a credit line to the material. If material is not included in the chapter's Creative Commons license and your intended use is not permitted by statutory regulation or exceeds the permitted use, you will need to obtain permission directly from the copyright holder.

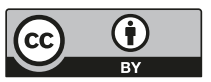

